\title{
Anti-oxidant Efficacy and Effects on Expression of Growth Factors in Human Hair Follicle Dermal Papilla Cells of Rosa multiflora Root Extracts
}

Hyeon Sook Hwang, Tae Hyun Hwang, Ae Ja Pyo, Eun Hwa Ju*

Department of Complementary and Alternative Medicine, Chosun University, Gwangju, Korea

\author{
*Corresponding author: Eun Hwa Ju, \\ Department of Complementary and Alternative \\ Medicine, Chosun University, 309 Pilmun- \\ daero, Dong-gu, Gwangju 61452, Korea \\ Tel.: +82 625715085 \\ Fax: +82 629700491 \\ Email:ffox000@naver.com
}

Received December 9, 2016

Revised March 20, 2017

Accepted May 6, 2017

Published June 30, 2017

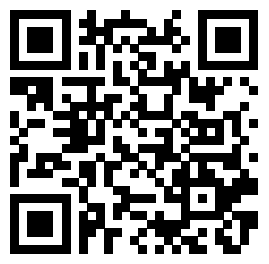

\begin{abstract}
Purpose: The anti-oxidant activity of active ingredients extracted from Rosa multiflora root was evaluated and effects of cell proliferation and growth factor expression were confirmed. Methods: Total polyphenol and flavonoid content of the active ingredients extracted from Rosa multiflora root was measured in various ways, as were 2,2-diphenyl-1-picrylhydrazyl (DPPH) radical scavenging activity and nitrite scavenging activity. Further, the cell proliferation effects for human hair follicle dermal papilla cell (HFDPC) were measured using thiazolyl blue tetrazolium bromide (MTT) assay, as were the effects of promoting the expression of growth factors such as platelet derived growth factor subunit B (PDGFB), keratinocyte growth factor (KGF), insulin like growth factor 1 (IGF1), vascular endothelial growth factor (VEGF), hepatocyte growth factor (HGF), and epidermal growth factor (EGF) by Western blot. Results: The total polyphenol content of six kinds of Rosa multiflora root extracts was the highest in supercritical extracts $(101.925 \mathrm{mg} / \mathrm{g})$ and the total flavonoid content was the highest in supercritical extracts $(14.365 \mathrm{mg} / \mathrm{g})$. DPPH scavenging activity was the highest in methanol-sonication extracts $(98.24 \%)$ and nitrite scavenging activity was the highest in supercritical extracts (55.86\%). HFDPC was treated with 10,100 , and $500 \mu \mathrm{g} / \mathrm{mL}$ of Rosa multiflora root methanol-sonication extracts to determine cytotoxicity. The cell growth rate increased with increasing concentrations. The effects of the expression of growth factor protein were 135\% greater in IGF1 and 126\% greater in PDGFB. Conclusion: Rosa multiflora root extracts had no cytotoxicity but had excellent anti-oxidant ability. In addition, because the effects of promoting the expression of IGF1 and PDGFB were significant, it was confirmed that Rosa multiflora root extracts could be used as an antioxidant, functional cosmetic material, and as a natural material for hair restorer and a hairgrowth promotion agent.
\end{abstract}

Keywords: Rosa multiflora, Human hair follicle dermal papilla cells, Western blot, Growth factor, MTT assay

\section{Introduction}

인간의 모발은 두개골 보호와 같은 본래의 기능 이외에도 미용적 인 면에서 큰 기능을 하고 있어 발모, 양모 및 탈모 예방은 예로부터 많은 관심의 대상이 되고 있다(Stenn et al., 1991). 또한 모발은 사 회생활에서 사람의 외모에 대한 이미지를 결정짓는 역할을 함으로 써 모발의 변화에 따라 자신감, 대인관계 등에 큰 영향을 미치기 때 문에 모발은 건강상뿐만 아니라 미용상으로도 매우 중요한 신체의
한 부분으로 인식되고 있다(Ryu \& Shin, 2011; Song \& Mo, 2010).

발모 및 탈모의 정확한 기전은 현재까지 완전하게 밝혀져 있지 않으나 탈모 유발원인으로는 남성호르몬 관여에 의한 모포 기능의 저하, 모포 및 모구부의 신진대사 기능의 저하, 두피 긴장에 의한 국소 혈류 장애, 영양불량, 스트레스, 약물에 의한 부작용, 유전적 요인, 자가면역, 국소감염, 화학물질, 백혈병, 결핵 등의 질병과 모 발제품의 남용 등으로 매우 다양하다(Liu et al., 2006).

모발성장을 촉진하는 약물로 미국 Food and Drug Administration 
(FDA)에서 지금까지 공인 받은 것은 미녹시딜(minoxidil)과 피나스 테리드(finasteride) 2종류 뿐이다. Hagemann et al. (2005)은 연 구에서 미녹시딜에 의한 모발성장효과는 6 개월에서 12 개월 이후에 나타나며 도포를 중단하면 급속하게 탈모가 진행되어 치료이전 상 태로 돌아가고 장기간 사용할 경우 두피의 가려움증, 홍반, 표피 벗 겨짐과 건성화를 동반한 피부염, 알레르기성 접촉성 피부염 및 지 루성 피부염을 일으킬 수 있다고 하였으며, Peters et al. (1996)은 미녹시딜을 사용할 경우 급격한 몸무게 증가, 부종, 심장 박동수 증 가, 협심증 및 혈액학적 부작용을 초래할 수 있다고 경고하였다. 피 나스테리드는 프로페시아(Propecia)라는 상품명으로 먹는 발모제 로 사용되고 있으며, 피나스테리드의 발모작용 기전은 명확히 밝혀 지지 않았지만 혈관확장을 통한 영양공급 증가 및 칼륨 통로를 여 는 효과 등이 모발성장을 유도하는 것으로 생각되고 있다. Shapiro \& Price (1998)은 피나스테리드는 육모의 효능은 우수하지만 모발 성장효과를 유지하기 위해서는 평생 동안 지속적으로 복용해야 하 는 단점이 있고, 남성의 성기능 장애와 가임 여성의 경우 기형아 출 산과 같은 부작용이 있어 안정성에 문제점이 있다고 하였다. 이러 한 부작용을 최소화하기 위해 최근 모발성장과 관련하여 천연물질 을 재료로 한 치료제 및 치료법에 대한 많은 연구가 진행되고 있으 며, 이러한 연구들은 천연물로부터 발모효과가 우수한 제제의 개발 가능성을 시사하였다(Hyung et al., 2007; Shin, 2006). 찔레나무 (Rosa multiflora)는 구창, 당뇨병, 심장질환을 치료하며 새살을 돋 게 하고 상처를 아물게 한다고 알려져 있으며, 찔레뿌리 추출물을 주성분으로 하는 조성물의 발모촉진효과에 대한 임상시험 연구가 발표되고 있어 기능성 소재와 새로운 발모촉진 치료제 등의 가능성 을 높여주고 있다(Kim et al., 2012).

모발을 잘 자라게 하기 위해서는 모유두(papilla)의 역할이 중요하 다. 모유두 세포는 발생학적으로 간엽계에서 유래된 세포로 주위의 상피계 세포의 분열을 조절하는 능력이 있으며, 이러한 기능은 성장 인자에 의해 조절된다고 알려져 있다(Randall et al., 2001). 현재까 지 모낭에서 발현되는 것으로 보고된 성장인자로는 인슐린유사성 장인자 1 (IGF1), 혈관내피성장인자(VEGF), 간세포성장인자(HGF), 각질형성세포성장인자 $(\mathrm{KGF})$, 섬유아세포성장인자 1 (fibroblast growth factor 1, FGF1) 등이 있다(Mitsui et al., 1997).

본 연구는 발모효과가 있으며 부작용이 없는 안전한 천연물 소 재 개발을 위하여 항산화효과가 우수하고 육모효과가 있는 것으 로 알려진 찔레뿌리로부터 다양한 방법으로 유효물질을 추출하여 항산화능 실험과 인간모유두세포의 증식효과와 Western blot으로 모낭에서 모발의 성장에 역할을 하는 성장인자의 발현촉진효과를 연구하여 약물 요법을 대체할 수 있는 천연성분을 이용한 모발성 장 및 탈모방지제 개발 가능성을 알아보고자 하였다.

\section{Methods}

\section{1. 실험재료 및 시약}

본 실험에 사용한 찔레뿌리는 서울 약령시장 부영약업사(Korea) 에서 국내산을 건조된 상태로 구입하여 사용하였다. 추출에 사용 된 유기용매 ethanol과 methanol은 Junsei Chemical (Japan)에 서 일급시약을 구입하였으며, acetic acid와 sodium hydroxide, hydrogen chloride (HCl)은 Duksan (Korea), sodium chloride $(\mathrm{NaCl})$ 은 Daejung (Korea) 제품을 구입 사용하였고, Tris- $\mathrm{HCl}$ 는 Difco $^{\text {TM }}$ (Becton, Dickinson and Company, USA)에서 구입 및 사용하였다. DPPH, L-ascorbic acid (vitamin C), tannic acid, naringin, sodium nitrite, diethylene glycol, griess reagent, MTT, tryptic soy broth, yeast extract, malt extract, peptone, dextrose, tryptone, bacto agar는 Sigma-Aldrich (USA)에서 구 입 및 사용하였다. Fetal bovine serum, antibiotic-antimycotic, ethylenediaminetetraacetic acid (EDTA)는 Gibco ${ }^{\mathrm{TM}}$ (Thermo Fisher Scientific, USA)에서 구입하였고, 세포배양에 사용한 인 간모유두세포(HFDPC)는 PromoCell (Germany)에서 구입하였 으며, 세포배양 배지는 HFDPC 세포배양 전용배지인 follicle dermal papilla cell growth medium (C-26501; PromoCell)을 사 용하였다. 모발성장인자 1차 항체인 혈소판유래성장인자 B 서브 유닛(PDGFB)와 HGF는 Santa Cruz Biotechnology (USA)에서, $\mathrm{KGF}$, IGF1, VEGF, 표피성장인자(EGF)는 PeproTech (USA)에 서, 2차 항체인 goat anti-rabbit IgG-horseradish peroxidase (HRP)는 Santa Cruz Biotechnology에서 구입 및 사용하였다.

\section{2. 실험방법}

1) 증류수 추출

찔레뿌리를 잘게 분쇄한 후 시료 $10 \mathrm{~g}$ 을 반응조 하부에 넣고 10 배 $(\mathrm{w} / \mathrm{v})$ 의 증류수를 부어서 임펠러(impellar), 반응조 하부, 반응조 상부, 냉각관(직류, 환류), 분액여두를 설치하고 약 $60 \mathrm{~min}$ 동안 약 재를 불린 후 $105^{\circ} \mathrm{C}$ 로 $120 \mathrm{~min}$ 간 전탕하여 찌꺼기를 따로 분리하 였다. 전탕액을 무균실에 있는 증류추출기에 넣고 $107^{\circ} \mathrm{C}$ 로 추출한 다음 PYREX병에 받은 후 무기염류를 침강시키기 위해서 하루 동 안 냉장 보관하였다. 무기염류를 침강시킨 침액은 무기염류를 제 외한 상층액을 분리하였다. 상층액을 $20 \mu \mathrm{m}$ filter (WM.1441042; Whatman ${ }^{\circledR}$, GE Healthcare Life Sciences, USA)로 3차 여과 후 rotary vacuum evaporation (N-1000; Eyela, Tokyo Rikakikai, Japan)으로 감압 증류하여 용매를 완전하게 휘발시킨 후 $-80^{\circ} \mathrm{C}$ 에 서 동결 건조한 후 $-20^{\circ} \mathrm{C}$ 에서 냉동 보관하여 사용하였다.

2) 유기용매 추출

찔레뿌리를 잘게 분쇄한 후 시료 $10 \mathrm{~g}$ 에 각각 $70 \%$ ethanol, $70 \%$ methanol를 가하여 총 $0.2 \mathrm{~L}$ 가 되도록 조절한 후 $72 \mathrm{~h}$ 동안 암 상 
태로 실온에 보관 추출하였다. 시료의 초음파 추출을 위해 Kwon et al. (2008)의 방법을 수정하여 위와 같은 조건으로 ethanol과 methanol 용매를 처리한 추출물을 준비하고 $30 \mathrm{~min}$ 동안 $60 \mathrm{kHz}$ 의 초음파를 발생시킨 후 $72 \mathrm{~h}$ 암 상태로 실온에 보관하여 추출하 였다. 추출물을 rotary vacuum evaporation으로 감압 증류하여 용매를 완전하게 휘발시킨 후 $-80^{\circ} \mathrm{C}$ 에서 동결 건조한 후 $-20^{\circ} \mathrm{C}$ 에서 냉동 보관하여 사용하였다.

\section{3) 초임계 추출}

찔레뿌리를 믹서로 $0.5 \mathrm{~mm}$ 이하로 분쇄한 후 열풍건조기로 $50^{\circ} \mathrm{C}$ 에서 $6 \mathrm{~h}$ 건조하여 수분 함량을 $5 \%$ 이하로 유지하였다. 건조 한 시료를 추출조에서 압력 $350 \mathrm{bar}$, 온도 $50^{\circ} \mathrm{C}$, 보조용매주입 유 량은 $6 \mathrm{~mL} / \mathrm{min}$ 으로 $70 \mathrm{~min}$ 동안 주입 추출하였다. 추출공정은 등 압, 퍼칭, 가압 후 압력 $150 \mathrm{bar}$ 에서 $20 \mathrm{~min}$ 동안 $\mathrm{CO}_{2}$ 유체를 이용 하여 추출한 추출물(A), 압력을 $350 \mathrm{bar}$ 까지 올리면서 보조용매로 에탄올을 주입하고 $10 \mathrm{~min}$ 동안 추출한 추출물(B), 압력은 $350 \mathrm{bar}$ 를 유지하면서 보조용매로 에탄올을 주입하고 $60 \mathrm{~min}$ 동안 추출한 추출물(C), 압력은 $350 \mathrm{bar}$ 를 유지하면서 보조용매는 주입하지 않 고 $10 \mathrm{~min}$ 간 추출한 추출물(D)을 구분하여 추출하였다(Table 1). 추출된 추출물(A, B, C, D)은 단계별 추출량을 계량 후 전량을 합 쳐 rotary vacuum evaporation으로 감압 증류하여 용매를 완전 하게 휘발시킨 후 $-80^{\circ} \mathrm{C}$ 에서 동결 건조하였다. 동결 건조된 각 분 말 시료는 사용 전까지 $-20^{\circ} \mathrm{C}$ 에서 냉동 보관하였다.

\section{4) 총 폴리페놀 함량 측정}

총 폴리페놀 함량은 Folin \& Denis (1913)의 방법을 수정하여 측정하였다. Methanol에 녹인 $1 \mathrm{mg} / \mathrm{mL}$ 농도의 시료 $100 \mu \mathrm{L}$ 을 microplate reader (Molecular Devices, USA)를 이용하여 760 $\mathrm{nm}$ 에서 흡광도를 측정하였다. 총 폴리페놀 함량은 methanol에

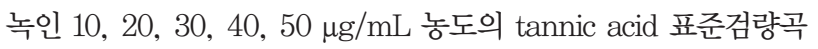
선을 이용하여 구하였다.

\section{5) 총 플라보노이드 함량 측정}

총 플라보노이드 함량은 Kim et al. (2012)의 방법으로 측정하였 으며 methanol로 녹인 $1 \mathrm{mg} / \mathrm{mL}$ 농도의 시료 $100 \mu \mathrm{L}$ 에 diethylene glycol을 $1 \mathrm{~mL}$ 씩 가하여 혼합하였다. 혼합 후 $1 \mathrm{~N}$ sodium hydroxide를 $100 \mu \mathrm{L}$ 가하여 잘 혼합하고 $37^{\circ} \mathrm{C}$ water bath에서 1 $\mathrm{h}$ 동안 반응시켰다. $1 \mathrm{~h}$ 후 microplate reader를 이용하여 $420 \mathrm{~nm}$ 에서 흡광도를 측정하였다. 표준물질로 naringin을 사용하였으며 $10,20,30,40,50 \mu \mathrm{g} / \mathrm{mL}$ 농도의 표준검량곡선을 작성하여 총 플라보노이드 함량을 환산하였다.

\section{6) $\mathrm{DPPH}$ 라디칼 소거능 측정}

$\mathrm{DPPH}$ 라디칼 소거능은 Kim et al. (2012)의 방법으로 측정
하였다. 시료는 methanol에 녹여 $1 \mathrm{mg} / \mathrm{mL}$ 농도로 준비하였으 며, $\mathrm{DPPH}$ 시약은 빛을 차단한 상태에서 $0.1 \mathrm{mM}$ 농도가 되도 록 methanol에 녹여 준비하였다. 시료 $100 \mu \mathrm{L}$ 와 DPPH 시약 0.5 $\mathrm{mL}$ 을 넣어 최종농도가 $0.2 \mathrm{mg} / \mathrm{mL}$ 로 혼합된 시료를 $20 \mathrm{~min}$ 동 안 빛을 차단한 조건에서 반응시킨 후 microplate reader를 이용 하여 $517 \mathrm{~nm}$ 에서 흡광도를 측정하였다. 음성대조군으로 시료 대 신 methanol을 사용하였고, 양성대조군으로는 시료 대신 ascorbic acid $(1 \mathrm{mg} / \mathrm{mL})$ 를 가하여 동일한 조건으로 실험을 수행하였다. $\mathrm{DPPH}$ 라디칼 소거능은 다음과 같은 식을 이용하여 $\mathrm{DPPH}$ 억제율 을 산출하였다.

DPPH radical scavenging activity $(\%)=[1-($ 시료 처리군의 흡 광도/시료 무처리군의 흡광도)] $\times 100$

\section{7) 아질산염 소거능 측정}

아질산염(nitrite) 소거능은 Gray \& Dugan (1975)의 방법으로 측 정하였다. $1 \mathrm{mM}$ sodium nitrite 용액 $50 \mu \mathrm{L}$ 에 $1 \mathrm{mg} / \mathrm{mL}$ 농도의 시 료 $50 \mu \mathrm{L}$ 를 첨가하고, 여기에 $0.1 \mathrm{~N} \mathrm{HCl}$ 용액(pH 1.2)을 $300 \mu \mathrm{L}$ 가하여 반응 용액의 최종부피를 $0.4 \mathrm{~mL}$ 로 하여 $37^{\circ} \mathrm{C}$ 에서 $1 \mathrm{~h}$ 반응 시켰다. 반응 후 $2 \%$ acetic acid 용액 $2 \mathrm{~mL}$, griess reagent $0.2 \mathrm{~mL}$ 을 가하여 최종농도가 $0.02 \mathrm{mg} / \mathrm{mL}$ 로 잘 혼합한 다음 실온에서 15 $\min$ 반응시키고 microplate reader를 이용하여 $520 \mathrm{~nm}$ 에서 흡광 도를 측정하여 잔존하는 아질산염의 양을 산출하였다. 대조군으로 시료 대신 증류수를 사용하였고, 음성대조군으로 griess reagent 대신 증류수를 사용하였고, 양성대조군으로는 시료 대신 ascorbic acid $(1 \mathrm{mg} / \mathrm{mL})$ 를 가하여 동일한 조건으로 실험을 수행하였다. 아 질산염 소거능은 다음과 같은 식을 이용하여 억제율을 산출하였다.

Nitrite scavenging activity $(\%)=[1-($ 시료 처리군의 흡광도/시료 무처리군의 흡광도) $] \times 100$

\section{8) HFDPC에 대한 in vitro 세포 독성 평가}

$\mathrm{HFDPC}$ 에 대한 MTT assay는 6종의 찔레뿌리 추출물 중 DPPH 라디칼 소거능이 가장 높은 메탄올 초음파 추출물을 선택하여 실험 하였다. 본 실험에서 세포의 배양과 계대배양 및 실험용 세포의 준비 는 PromoCell에서 제공하는 실험법에 준하여 수행하였다. HFDPC 에 미치는 생존율 측정은 Mosmann (1983)의 방법을 응용하여 실 시하였다. 시험 추출물인 찔레뿌리 메탄올-초음파 추출물을 대 조군과 함께 처리하였으며 대조군으로 샘플을 용해하는데 사용된 phosphate buffered saline (PBS; Thermo Fisher Scientific)을 동량 으로 처리하였다. 천연 추출물은 배양 배지 $1 \mathrm{~mL}$ 에 대하여 $50 \mu \mathrm{L}$ 처 리 후 최종 농도가 $10,100,500 \mu \mathrm{g} / \mathrm{mL}$ 이 되도록 처리하였다. 배양 완료 후 $100 \mu \mathrm{L}$ 의 MTT solution을 각 well에 첨가하고 $3 \mathrm{~h}$ 동안 추가 로 세포 배양기에서 배양하여 MTT가 환원되도록 하였다. 배양액을 
완전히 제거한 후 microplate reader를 이용하여 $550 \mathrm{~nm}$ 에서 흡광 도를 측정하였다.

9) Western blot을 통한 모발성장인자 단백질 발현 측정

$\mathrm{HFDPC}$ 를 계대 배양한 후 찔레뿌리 메탄올-초음파 추출물 을 $100 \mu \mathrm{g} / \mathrm{mL}$ 의 농도로 처리한 후 $48 \mathrm{~h}$ 뒤에 세포에서 발현되 는 6가지의 성장인자 PDGFB, KGF, IGF1, VEGF, HGF, EGF 단백질들의 발현을 sodium dodecyl sulfate-polyacrylamide gel electrophoresis (SDS-PAGE)로 분리하고 Western blot을 이용하 여 측정하였다. $\mathrm{HFDPC}$ 를 $48 \mathrm{~h}$ 배양한 후 $\mathrm{PBS}$ 로 2 회 세척하고, $2 \%$ NET buffer (150 mM NaCl; 5 mM EDTA, pH 8; 50 mM Tris$\mathrm{HCl}, \mathrm{pH}$ 7.4)를 이용하여 세포를 용해하고 sonication을 통해 세포 추출물을 제조하였다.

세포추출물의 단백질 정량은 bovine serum albumin을 표준물 질로 간략하게 Quick Start ${ }^{\mathrm{TM}}$ Bradford Protein Assay (Bio-Rad Laboratories, USA)를 이용하여 정량하였다. 단백질을 정량한 시 료는 각 well 당 $20 \mu \mathrm{g}$ 의 단백질량을 로딩하여 $10 \% \mathrm{SDS}-\mathrm{PAGE}$ 에 서 $150 \mathrm{~V}$ 로 $1 \mathrm{~h}$ 전기영동하고 electro-blotter (Gel company, USA) 를 사용하여 $70 \mathrm{~V}$ 로 $30 \mathrm{~min}$ 처리하여 nylon membrane filter (Sigma-Aldrich)에 옮기고 5\% skim milk solution에 filter를 담그 고 $12 \mathrm{~h}$ 배양하였다. 이후 $\mathrm{PBS}$ 세척액으로 $10 \mathrm{~min}$ 간 3 회 세척하고 2,500배 희석된 1차 항체 PDGFB, KGF, IGF1, VEGF, HGF, EGF 를 이용하여 $1.5 \mathrm{~h}$ 반응시켰으며 세척액으로 3 회 세척한 후 2,500 배 희석된 2 차 항체 goat anti-rabbit IgG-HRP를 $1 \mathrm{~h}$ 반응시키 고 세척액으로 3 회 세척한 후 ECL kit (RPN 2108; Amersham ${ }^{\mathrm{TM}}$, $\mathrm{GE}$ Healthcare Life Sciences)를 이용하여 필름에 감광시키는 방 법을 이용하여 단백질의 발현을 조사하였다. Band density는 gel imaging system (Gel Doc ${ }^{\mathrm{TM}}$ EZ system 1708270; Bio-Rad Laboratories)으로 확인하였다.

\section{3. 통계처리}

모든 시료의 분석은 3 번 반복 수행되었고, 실험결과는 Statistical Package for the Social Sciences package program (SPSS Ver. 21; IBM, USA)을 사용하여 mean \pm standard deviation (M $\pm \mathrm{SD}$ )로 표시하였고 통계분석은 Student's t-test로 분석하였으며 $p<0.05$ 값을 유의성 있는 것으로 해석하였다.

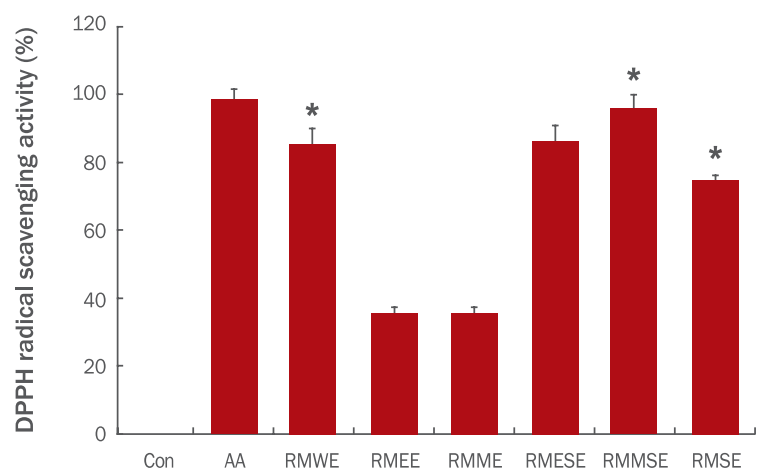

Figure 1. DPPH radical scavenging activity of Rosa multiflora root extracts.

Anti-oxidant effects were measured by DPPH radical scavenging activity and the final concentration of the sample was $0.2 \mathrm{mg} /$ $\mathrm{mL}$. DPPH scavenging activity was the highest in RMMSE. Values represent $\mathrm{M} \pm$ S.D. of triplicate determinations. ${ }^{*} p<0.05$ vs. control group. DPPH, 2,2-diphenyl-1-picrylhydrazyl; Con, control (vehicle), negative control group; $\mathrm{AA}$, ascorbic acid $(1 \mathrm{mg} / \mathrm{mL})$, positive control group; RMWE, Rosa multiflora water extracts; RMEE, Rosa multiflora ethanol extracts; RMME, Rosa multiflora methanol extracts; RMESE, Rosa multiflora ethanol-sonication extracts; RMMSE, Rosa multiflora methanol-sonication extracts; RMSE, Rosa multiflora supercritical extracts; M \pm S.D., mean \pm standard deviation.

\section{Results}

\section{1. 추출 수율}

찔레뿌리에 대한 용매와 추출방법을 달리한 추출 수율은 증류수 추출에서 $17.4528 \%$ 로 가장 높게 나타났다(Table 2).

\section{2. 총 폴리페놀 함량}

찔레뿌리 추출물 6 종의 총 폴리페놀 함량을 분석한 결과, 초임계 추출물에서 $101.925 \pm 3.262 \mathrm{mg} / \mathrm{g}$ 으로 가장 높았으며, 메탄올-초 음파 추출물에서 $58.046 \pm 3.251 \mathrm{mg} / \mathrm{g}$, 에탄올-초음파 추출물에 서 $50.655 \pm 4.711 \mathrm{mg} / \mathrm{g}$, 증류수 추출물에서 $43.232 \pm 3.329 \mathrm{mg} /$ $\mathrm{g}$, 메탄올 추출물에서 $14.522 \pm 1.597 \mathrm{mg} / \mathrm{g}$, 에탄올 추출물에서 $9.448 \pm 0.831 \mathrm{mg} / \mathrm{g}$ 순서로 나타났다(Table 3).
Table 1. Extraction conditions for supercritical extraction group

\begin{tabular}{lll}
\hline & Extraction tank & Pressure $(350$ bar $)$, Temperature $\left(50^{\circ} \mathrm{C}\right)$ \\
& Auxiliary solvent flow rate & $6 \mathrm{~mL} / \mathrm{min}$, Injection for $70 \mathrm{~min}$ \\
Extraction condition & Separator tank & Pressure $\left(40\right.$ bar), Temperature $\left(40^{\circ} \mathrm{C}\right)$ \\
& $\mathrm{CO}_{2}$ flow rate & $60 \mathrm{~mL} / \mathrm{min}$ \\
& Cooler & $-2^{\circ} \mathrm{C}$ \\
\hline & Run-time & $120 \mathrm{~min}$ \\
\hline
\end{tabular}




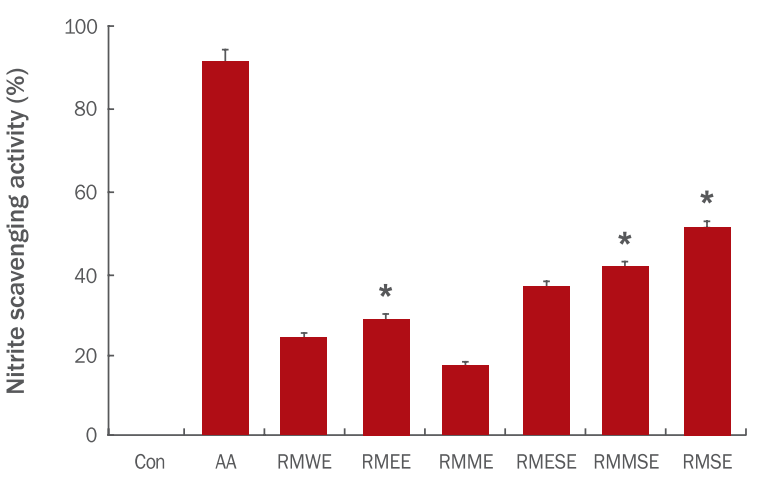

Figure 2. Nitrite scavenging activity of Rosa multiflora root extracts.

Nitrite scavenging activity of solvent extracts from Rosa multiflora root extracts. The final concentration of the sample was $0.02 \mathrm{mg} /$ $\mathrm{mL}$. Nitrite scavenging activity was the highest in RMSE. Values represent $\mathrm{M} \pm \mathrm{S}$.D. of triplicate determinations. ${ }^{*} p<0.05$ vs. control group. Con, control (vehicle), negative control group; AA, ascorbic acid (1 mg/mL), positive control group; RMWE, Rosa multiflora water extracts; RMEE, Rosa multiflora ethanol extracts; RMME, Rosa multiflora methanol extracts; RMESE, Rosa multiflora ethanol-sonication extracts; RMMSE, Rosa multiflora methanolsonication extracts; RMSE, Rosa multiflora supercritical extracts.

\section{3. 총 플라보노이드 함량}

찔레뿌리 추출물 6 종의 총 플라보노이드 함량을 분석한 결과, 초 임계 추출물에서 $14.365 \pm 1.508 \mathrm{mg} / \mathrm{g}$ 으로 가장 높았으며, 메탄 올-초음파 추출물에서 $4.046 \pm 0.303 \mathrm{mg} / \mathrm{g}$, 에탄올-초음파 추 출물에서 $2.679 \pm 0.147 \mathrm{mg} / \mathrm{g}$, 증류수 추출물에서 $0.051 \pm 0.002$ $\mathrm{mg} / \mathrm{g}$ 순서로 총 플라보노이드 함량이 나타났으며, 에탄올 추출물 과 메탄올 추출물에서는 총 플라보노이드가 검출되지 않은 것으로 분석되었다(Table 4).

\section{DPPH 라디칼 소거능}

찔레뿌리 추출물 6 종의 $\mathrm{DPPH}$ 라디칼 소거능을 분석한 결과, 메 탄올-초음파 추출물은 $98.24 \%$ 의 가장 높은 $\mathrm{DPPH}$ 라디칼 소거능 을 보였다. 다음으로 에탄올-초음파 추출물(87.87\%), 증류수 추

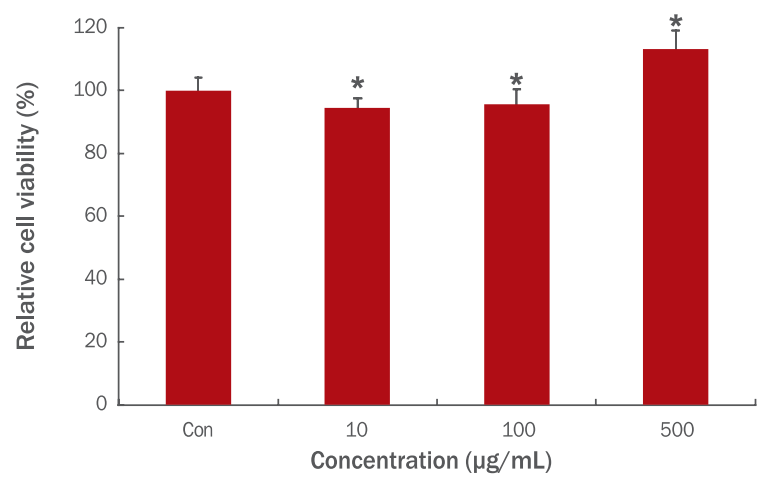

Figure 3. Effects of methanol-sonication extracts from Rosa multiflora root on the cell viability of HFDPCs.

Cell viability was measured by MTT assay. No cytotoxicity was observed within the treatment concentration range. Values represent $\mathrm{M} \pm$ S.D. of triplicate determinations. ${ }^{*} p<0.05$ vs. control group. Con, control (vehicle), negative control group; HFDPC, human hair follicle dermal papilla cell; MTT, thiazolyl blue tetrazolium bromide.

출물(87.28\%), 초임계 추출물(76.39\%), 에탄올 추출물(35.85\%), 메탄올 추출물(35.80\%) 순서로 $\mathrm{DPPH}$ 라디칼 소거능이 나타났다 (Figure 1).

\section{5. 아질산염 소거능}

아질산염 소거능 분석은 양성대조군으로 $1 \mathrm{mg} / \mathrm{mL}$ 농도의 ascorbic acid를 사용하였으며, ascorbic acid의 아질산염 소거능 은 $90.73 \pm 5 \%$ 로 나타났다. 찔레뿌리 추출물 6 종의 아질산염 소거 능을 분석한 결과, 초임계 추출물(55.86\%)이 가장 높은 효과를 보 였으며, 그 다음으로 메탄올-초음파 추출물(40.86\%), 에탄올초음파 추출물(37.41\%), 에탄올 추출물(27.59\%), 증류수 추출물 (22.76\%), 메탄올 추출물(18.28\%) 순서로 아질산염 소거능이 나타 났다(Figure 2).

\section{HFDPC에 대한 in vitro 세포 독성 평가}

$\mathrm{HFDPC}$ 에 찔레뿌리 메탄올 초음파 추출물을 $10,100,500 \mu \mathrm{g} /$ $\mathrm{mL}$ 의 농도별로 처리하여 MTT assay로 세포 독성을 확인한 결과,

Table 2. Extracted yield in water, ethanol, methanol, ethanol-sonication, methanol-sonication, and supercritical extraction from Rosa multiflora root

\begin{tabular}{lll}
\hline & Methods of extraction & Extracted yield (\%) \\
\cline { 2 - 3 } & Water extraction & 17.4528 \\
& Ethanol extraction & 14.6540 \\
& Methanol extraction & 15.0476 \\
& Ethanol-sonication extraction & 15.2075 \\
& Methanol-sonication extraction & 16.3886 \\
& Supercritical extraction & 16.3248 \\
\hline
\end{tabular}


A

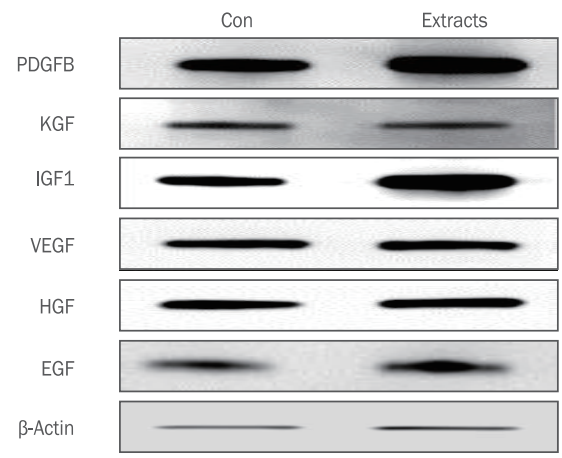

B

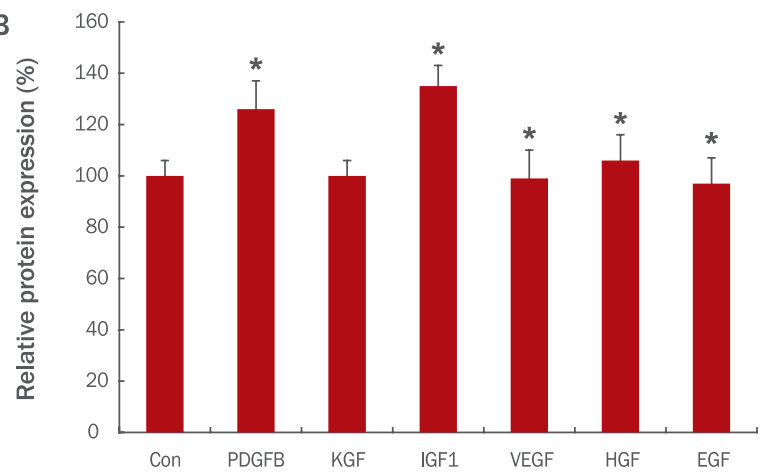

Figure 4. Effects of methanol-sonication extracts from Rosa multiflora root on protein expression.

Expression of growth factors (PDGFB, KGF, IGF1, VEGF, HGF, and EGF) were analyzed by Western blot (A) and its relative statistical results are presented in this bar graph (B). In comparison with Con, the expression level of IGF1 (135\%) and PDGFB (126\%) was significantly increased and HGF, KGF, VEGF, and EGF was 106\%, 100\%, 99\%, and 97\%, respectively. Values represent M \pm S.D. of triplicate determinations. " $p<0.05$ vs. control group. Con, control (vehicle), negative control group; PDGFB, platelet derived growth factor subunit B; KGF, keratinocyte growth factor; IGF1, insulin like growth factor 1; VEGF, vascular endothelial growth factor; HGF, hepatocyte growth factor; EGF, epidermal growth factor.

처리 농도 범위 내에서는 유의적인 세포 독성은 관찰되지 않았다. $\mathrm{PBS}$ 를 처리한 대조군 대비, $10 \mu \mathrm{g} / \mathrm{mL}$ 처리는 $94.4 \pm 3 \%, 100 \mu \mathrm{g} /$ $\mathrm{mL}$ 처리는 $95.5 \pm 5 \%, 500 \mu \mathrm{g} / \mathrm{mL}$ 처리는 $113.1 \pm 6 \%$ 의 세포 생육도 를 보였다(Figure 3).

\section{7. 모발성장인자 단백질 발현촉진효과}

$\mathrm{HFDPC}$ 에 찔레뿌리 메탄올 초음파 추출물을 $100 \mu \mathrm{g} / \mathrm{mL}$ 의 농도로 $48 \mathrm{~h}$ 처리한 후 모발성장인자 단백질인 PDGFB, $\mathrm{KGF}, \mathrm{IGF1}, \mathrm{VEGF}$,
$\mathrm{HGF}, \mathrm{EGF}$ 의 발현 정도에 미치는 영향을 Western blot을 통해 측정하였 다. 찔레뿌리 메탄올 초음파 추출물 처리 시 대조군과 대비하여 IGF1

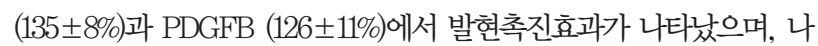
머지 모발성장인자에서는 $\mathrm{HGF}(106 \pm 10 \%), \mathrm{KGF}(100 \pm 6 \%), \mathrm{VEGF}$

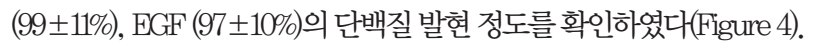

Table 3. Total polyphenol content of Rosa multiflora root extracts

\begin{tabular}{llc}
\hline & Methods of extraction & Polyphenol content (mg/g) \\
\cline { 2 - 3 } & Water extraction & $43.232 \pm 3.329$ \\
\cline { 2 - 2 } Rosa multiflora root extracts & Ethanol extraction & $9.448 \pm 0.831$ \\
\cline { 2 - 3 } & Methanol extraction & $14.522 \pm 1.597$ \\
\cline { 2 - 3 } & Ethanol-sonication extraction & $50.655 \pm 4.711$ \\
\cline { 2 - 3 } & Methanol-sonication extraction & $58.046 \pm 3.251$ \\
\hline & Supercritical extraction & $101.925 \pm 3.262$ \\
\hline
\end{tabular}

Values represent $\mathrm{M} \pm$ S.D. of triplicate determinations.

Table 4. Total flavonoid content of Rosa multiflora root extracts

\begin{tabular}{llc}
\hline & Methods of extraction & Flavonoid content $(\mathrm{mg} / \mathrm{g})$ \\
\cline { 2 - 3 } & Water extraction & $0.051 \pm 0.002$ \\
\cline { 2 - 2 } & Ethanol extraction & $0.000 \pm 0.000$ \\
& Methanol extraction & $0.000 \pm 0.000$ \\
& Ethanol-sonication extraction & $2.679 \pm 0.147$ \\
\cline { 2 - 3 } & Methanol-sonication extraction & $4.046 \pm 0.303$ \\
\hline & Supercritical extraction & $14.365 \pm 1.508$ \\
\hline
\end{tabular}

Values represent $\mathrm{M} \pm$ S.D. of triplicate determinations. 


\section{Discussion}

찔레나무(Rosa multiflora Thunberg)는 장미과(Rosaceae)에 속 하며 한의학에서는 석산호(石冊湖)로 불리고 있으며, 열매는 영실 (營實) 또는 색미자(嗇薇子)라 하여 약으로 귀하게 쓰인다. 뿌리는 청열(清熱), 이습(利濕), 거풍(祛風), 활혈(活血)에 효능이 있어 당 뇨병, 이질, 관절염, 토혈, 유뇨증, 월경불순, 타박상의 치료목적으 로 민간에서 사용되어 왔다(Beom et al., 2010). 찔레나무의 성분 으로는 주로 찔레의 과실인 영실로부터 multiflorin A, multiflorin $\mathrm{B}$, kaempferol $3-\mathrm{O}-\alpha-\mathrm{L}-\mathrm{rhamnoside,} \mathrm{multinoside} \mathrm{A}$ 와 그 acetate, quercitrin, isoquercitrin, quercetin 3-O-xyloside, hyperin 등의 flavonoid류와 scoparone, salicylic acid, sterol 등이 보고되어 있다(Takagi et al., 1980).

항산화 활성이란 생체 내 활성산소의 생성을 방지하고 세포에 회복 불가능한 손상을 야기하는 산화현상을 방지하는 활성을 말한 다. 안정한 상태의 산소(triplet oxygen)는 환경적 및 생화학적 요인 등에 의해 반응성이 큰 활성산소(reactive oxygen species)로 전환 되어 세포 구성 성분을 비가역적으로 파괴한다고 하였다(Huang et al., 1992). 이와 같은 활성산소를 억제하는 효과가 있는 항산화제 는 대부분 식물 기원의 항산화성 화합물로서 나무, 수피, 줄기, 잎, 과일, 뿌리, 꽃, 열매, 씨앗 등의 모든 부위에 존재하며, 주로 페놀 화합물 구조를 가지면서 지질의 자동산화 조건에 의해 생성된 유리 라디칼의 생성을 지연시키거나 활성을 저해하는 역할을 한다(Cha et al., 1999).

폴리페놀 화합물은 천연식물에 널리 분포되어 있는 방향족 화합 물로서 산화를 방지하는 작용 즉, 항산화능을 가지며 식물 체내의 2 차 대사물로 항산화, 항균 등 다양한 생리활성을 나타낸다. 따라 서 식물체가 지니고 있는 페놀 화합물의 함량을 조사하는 것은 천 연추출물의 항산화 활성을 탐색하는 일차적인 자료가 될 뿐만 아 니라, 식품을 비롯한 화장품 원료 개발의 기초 자료로서 활용될 가 능성이 높다(Choi et al., 2004; Park, 1999). Hwang et al. (2010) 은 비파 잎 에탄올 추출물의 폴리페놀 함량이 $32.32 \mathrm{mg} / \mathrm{mL}$ 로 나 타났다고 하였으며, Oh (2013)는 흰 민들레 뿌리 에탄올 추출물의 폴리페놀 함량이 $32.90 \mathrm{mg} / \mathrm{g}$ 으로 보고하였고, Park et al. (2011) 은 찔레나무 뿌리에 존재하는 총 폴리페놀 함량은 아세톤 추출물에 서 $67.05 \mathrm{mg} / \mathrm{g}$ 으로 제일 높게 나타났다고 하였다. 본 연구에서 찔 레뿌리 추출물의 총 폴리페놀 함량은 초임계 추출물에서 101.925 $\mathrm{mg} / \mathrm{g}$ 로 나타나 Park et al. (2011)의 연구보다 높았으며, 비파 잎, 흰 민들레 뿌리 추출물의 폴리페놀 함량보다 찔레뿌리 추출물의 폴 리페놀 함량이 상대적으로 높은 것을 알 수 있었다.

플라보노이드는 식물에서 합성되는 폴리페놀류의 가장 큰 부류 에 속하며 지방질의 산화, 활성 산소의 소거 및 산화적 스트레스 를 경감하는 역할을 함으로써 오늘날 식품, 의약품, 화장품 등 여러 분야에서 활용되고 있다(Hertog \& Hollman, 1996). Ryu \& Jeong
(2012)은 연구에서 선학초 에탄올 추출물의 플라보노이드 함량을 $32.8 \mathrm{mg} / \mathrm{g}$, Hwang et al. (2011)은 미나리 에탄올 추출물의 플라보 노이드 함량을 $26.5 \mathrm{mg} / \mathrm{g}$ 으로 보고하였으며, Park et al. (2014)은 블루베리 열수 추출물의 플라보노이드 함량이 $5.2 \mathrm{mg} / \mathrm{g}$ 으로 나타 났으며, Kim \& Lee (2013)은 참마 열수 추출물의 플라보노이드 함 량이 $8.22 \mathrm{mg} / \mathrm{g}$ 으로 나타났다고 보고하였다. 본 연구에서 찔레뿌 리 초임계 추출물의 총 플라보노이드 함량은 $14.365 \mathrm{mg} / \mathrm{g}$ 으로 나 타났는데 이는 선학초 에탄올 추출물, 미나리 에탄올 추출물의 플 라보노이드 함량보다는 낮았으나, 블루베리 열수 추출물, 참마 열 수 추출물의 플라보노이드 함량보다 높은 결과이다.

$\mathrm{DPPH}$ 라디칼 소거능은 불안정한 유리기에 환원기능을 가진 proton을 제공하여 안정화 되도록 유도하는 기능으로 생체 내에 서 발생하는 불안정하고 유해한 유리기를 안정화시키는 역할을 한 다. 따라서 미지의 특정물질이 생체의 생리작용 혹은 산화작용에 의하여 발생하는 hydroxyl radical 혹은 superoxide radical 등을 제거하는 항산화 능력을 평가할 때 사용되는 지표로 높은 값일수 록 항산화능이 우수한 것으로 판단한다(Lee et al., 2011). Park et al. (2011)의 연구에서 찔레뿌리의 전자공여능을 측정한 결과, 열 수 추출물의 경우 $50 \mu \mathrm{g} / \mathrm{mL}$ 에서 $40 \%$ 이상의 효능을 보였고, 에 탄올, 메탄올 및 아세톤 추출물의 경우 $100 \mu \mathrm{g} / \mathrm{mL}$ 에서 $80 \%$ 이 상의 효과를 나타내어 같은 농도의 양성대조군 vitamin $\mathrm{C}$ 보다 우 수한 radical 소거능을 나타내었다고 보고하였다. Han (2006)은 연구에서 찔레뿌리 아세톤 추출물의 half maximal scavenging concentration $\left(\mathrm{SC}_{50}\right)$ 값이 $7.6 \mu \mathrm{g} / \mathrm{mL}$ 로 나타나 합성 항산화제인 butylated hydroxytoluene의 $\mathrm{SC}_{50}$ 값인 $9.2 \mu \mathrm{g} / \mathrm{mL}$ 와 비교하였을 때 높은 항산화 활성을 갖는다고 하였다. 본 연구에서 나타난 찔레 뿌리 메탄올-초음파 추출물의 DPPH 소거능은 $98.24 \%$ 로 나타나 Han (2006)의 연구 결과와 일치하였으며, Park et al. (2011)의 연 구결과보다 높게 나타났다.

아질산염은 산화제와 환원제로 작용하며 생체 내에서 nitric oxide synthase라는 효소의 촉매작용을 통해 L-arginine으로부 터 변환되는 반응성이 강한 자유 라디칼로, 질산염(nitrate)은 아 질산염으로 환원되고 amine류와 반응하여 nitrosamine을 생성하 는 것으로 알려져 있으며, nitrosamine은 체내에서 diazoalkane $\left(\mathrm{C}_{\mathrm{n}} \mathrm{H}_{2 \mathrm{n}} \mathrm{N}_{2}\right)$ 으로 변화하여 핵산이나 단백질 또는 세포내의 성분을 알 킬화하여 암을 유발하고, 그 자신이 독성을 가지고 있다고 하였다 (Bartsch et al., 1988). 따라서 아질산염을 소거하여 nitrosamine 의 생성을 억제할 수 있는 인체에 안전한 천연물은 기능성 화장품 이나 식품보존제 및 천연 산패방지제로서 사용 가능할 것이라 사 료된다. 본 연구에서 나타난 찔레뿌리 추출물의 아질산염 소거능 은 초임계 추출물 $55.86 \%$ 로 나타났다. 이는 Park et al. (2002)의 쑥과 솔잎 물 추출물의 $100 \mathrm{ppm}$ 농도에서 아질산염 소거작용이 쑥 은 $10 \%$ 미만, 솔잎은 $11 \%$ 로 나타났다는 보고와 Han et al. (2011) 의 민들레의 꽃, 잎, 뿌리, 전체 추출물 $1 \mathrm{mg} / \mathrm{mL}$ 에서 각각 $47.3 \%$, 
$47.1 \%, 41.5 \%, 30.0 \%$ 의 아질산염 소거 활성을 나타냈다는 보고와 비교하였을 때 찔레뿌리 추출물의 아질산염 소거능이 높다는 것을 알 수 있었다.

Kim et al. (2012)은 찔레뿌리 추출물의 발모효과를 검토하기 위 하여 실험동물에 대조군, $5 \%$ 미녹시딜 처리군, $5 \%$ 찔레뿌리 추출 물 처리군을 처리한 결과, 도포 1 주 후, 찔레뿌리 추출물 처리군이 두드러진 모발성장을 나타냈었고, 도포 2주 후, 대조군은 약 $80 \%$ 정도의 모발성장을 나타낸 반면, $5 \%$ 미녹시딜 처리군과 $5 \%$ 찔레뿌 리 추출물 처리군은 거의 완전히 발모가 된 상태로 관찰되었다고 하였다.

Park et al. (2011)은 찔레뿌리 추출물의 macrophage cell에 대한 독성을 확인한 결과, 찔레나무 뿌리 열수, 에탄올, 메탄올, 아세톤 추출물 $1,000 \mu \mathrm{g} / \mathrm{mL}$ 을 첨가한 군에서 각 $52.7 \%, 42.0 \%, 52.1 \%$, $58.9 \%$ 의 세포 독성을 보였으나, $100 \mu \mathrm{g} / \mathrm{mL}$ 에서는 세포 독성이 없 는 것으로 나타났다. 본 연구에서는 찔레뿌리 메탄올-초음파 추출 물 $10,100,500 \mu \mathrm{g} / \mathrm{mL}$ 의 농도 범위 내에서는 $\mathrm{HFDPC}$ 에 대한 유 의적인 세포 독성은 관찰되지 않았으며, $500 \mu \mathrm{g} / \mathrm{mL}$ 처리 시 PBS 를 처리한 대조군 대비 $113.1 \%$ 의 세포 생육도를 보여 Park et al. (2011)의 연구와 일치하였으며, Kim et al. (2012)의 찔레뿌리 추출 물의 발모효과가 관찰되었다는 보고와 연관하여 볼 때 육모제 소재 로서 개발 가능성이 높다는 것을 알 수 있었다.

성장인자의 모발성장에 미치는 영향에 관해서는 EGF, IGF, $\mathrm{FGF}, \mathrm{VEGF}$ 등의 성장인자들은 여러 실험을 통하여 모낭의 특 정 장소에 작용하여 모발성장에 관여한다고 이미 밝혀진 바 있 다(Tsuboi, 1997). 1994년에는 Hervert 연구팀에서 섬유아세포 성장인자인 FGF5 유전자가 결핍된 쥐가 비정상적으로 모발성 장기(anagen phase)가 길어져 모발이 상대적으로 길어지며, $\mathrm{FGF} 7, \mathrm{IGF} 1, \mathrm{HGF}$ 는 모발성장을 촉진시키는 주변 분비 성장인자 (paracrine growth factor)라고 보고하였으며(Lin et al., 2015), 발모 및 탈모에 영향을 미치는 내분비계인자 중 transforming growth factor beta 1 (TGFß1)은 모발성장기의 성장을 방해하여 정 상보다 빨리 퇴행기(catagen phase)로 접어들게 하여 탈모를 유도 하고 $\mathrm{IGF} 1, \mathrm{TGF} 32, \mathrm{EGF}, \mathrm{FGF}$ 등의 성장인자는 모발의 성장을 촉 진하고 모발세포의 퇴화를 방지하여 탈모를 방지한다고 하였다.

Su et al. (1999)은 쥐를 이용한 여러 가지 실험을 통해 피부에 $\mathrm{IGF1}$ 을 과 발현시킨 실험군에서 모낭의 발달이 빨라졌고, IGF1은 survival factor로서 세포사멸을 방지하는 anti-apoptotic 효과가 있다는 것을 확인하였다. 이런 효과는 모낭세포가 퇴행기를 지남에 따라 퇴화되는 것을 방지시켜주는 역할을 하게 된다고 하였다.

Yano et al. (2001)은 연구에서 VEGF는 모낭의 성장과정에서 혈 관생성에 관여하는 중요한 인자로 대두되었고, 여러 동물실험에 서 VEGF가 모낭주위의 미세혈관을 생성시키는 것뿐만 아니라 탈 모 후 자라나는 모발의 크기를 증가시키고 성장속도를 촉진시킨다 는 것을 알게 되었다고 하였다. Stenn et al. (1988)은 VEGF를 이
용하여 모낭 주위에 새로운 혈관을 형성하는 모낭은 표피의 깊은 곳에 존재하는 vascular plexus에서 유래하는 미세한 혈관들로 둘 러 쌓여있는데, 성장기에 존재하는 모낭들은 angiogenic한 성질 을 지니고 있어 perifollicular vascularization이 활발히 일어난다 는 것이 확인하였다. 모낭 각질형성세포는 모유두세포와 상호작용 하며 모낭의 형성과 모낭주기의 조절에 있어 중요한 역할을 한다. $\mathrm{KGF} 2$ 는 모유두에 존재하며 이의 수용체는 이웃하고 있는 외모근 초의 각질형성세포에 존재한다. 이와 관련하여 재조합 $\mathrm{KGF} 2$ 를 주 입하였을 때 모낭 내 세포들이 증식한다는 연구결과도 있다(Yano et al., 2001). 본 연구에서는 찔레뿌리 메탄올-초음파 추출물(100 $\mu \mathrm{g} / \mathrm{mL}$ )의 IGF1, PDGFB 발현촉진효과가 대조군 대비 각각 $135 \%$, $126 \%$ 로 높게 나타났으나, $\mathrm{HGF}, \mathrm{KGF}, \mathrm{VEGF}, \mathrm{EGF}$ 의 발현촉진효 과는 찔레뿌리 추출물에서 대조군 대비 차이가 나타나지 않았다.

\section{Conclusion}

본 연구자는 찔레뿌리로부터 다양한 방법으로 유효물질을 추출 하여 기능성 화장품 및 육모제 소재로의 활용 가능성을 알아보았 다. 찔레뿌리에서 추출방법을 달리하여 추출한 각 6 종 추출물의 총 폴리페놀 함량은 초임계 추출물에서 $101.925 \mathrm{mg} / \mathrm{g}$ 으로 가장 높게 나타났다. 총 플라보노이드 함량은 초임계 추출물에서 $14.365 \mathrm{mg} /$ $\mathrm{g}$ 으로 가장 높게 나타났으며, $\mathrm{DPPH}$ 소거능은 메탄올-초음파 추 출물에서 $98.24 \%$ 로 가장 높은 효과를 나타내었다.

아질산염 소거능은 초임계 추출물에서 $55.86 \%$ 로 가장 높은 효 과를 보였다. 찔레뿌리 메탄올-초음파 추출물의 $\mathrm{HFDPC}$ 에 대한 세포 독성은 $10,100,500 \mu \mathrm{g} / \mathrm{mL}$ 의 농도 범위 내에서 유의적인 세 포 독성은 관찰되지 않았으며, $\mathrm{HFDPC}$ 생육도는 $10 \mu \mathrm{g} / \mathrm{mL}$ 처리는 $94.4 \%, 100 \mu \mathrm{g} / \mathrm{mL}$ 처리는 $95.5 \%, 500 \mu \mathrm{g} / \mathrm{mL}$ 처리는 $113.1 \%$ 로 나타나 농도가 증가할수록 세포 생육도가 높게 나타났다.

찔레뿌리 메탄올-초음파 추출물의 모발성장인자 단백질 발현 촉진효과는 대조군 대비 IGF1은 $135 \%, \mathrm{PDGFB}$ 는 $126 \%$ 의 발현촉 진효과가 나타났으나, $\mathrm{HGF}$ 는 $106 \%, \mathrm{KGF}$ 는 $100 \%$, VEGF는 $99 \%$, $\mathrm{EGF}$ 에서는 $97 \%$ 로 각각 나타나 대조군과 발현촉진효과의 차이가 나타나지 않았다.

본 연구에서 찔레뿌리 추출물은 폴리페놀과 플라보노이드 함량 이 높고, $\mathrm{DPPH}$ 라디칼 소거능과 아질산염 소거능이 높게 나타나, 피부의 노화억제 및 보호효과가 기대되어 화장품 및 피부보호 소재 로서 활용가치가 있는 것을 확인하였다. 또한 $\mathrm{HFDPC}$ 에 대한 세포 독성이 없고 세포증식효과가 있으며 IGF1, PDGFB의 발현촉진효 과를 나타내고 있어 육모제 및 발모촉진제 천연소재로의 활용 가능 성을 확인하였다. 


\section{References}

Bartsch H, Ohshima H, Pignatelli B. Inhibitors of endogenous nitrosation mechanisms and implications in human cancer prevention. Mutation Research/Fundamental and Molecular Mechanisms of Mutagenesis, 202: 307-324, 1988.

Beom HJ, Kim R, Kim HS. The physicochemical properties of sweet flag (Acorous calamus L.) and the effects on skin protection of its ethanol extracts by UVB. Asian Journal of Beauty and Cosmetology, 8: 181-194, 2010.

Cha JY, Kim HJ, Chung CH, Cho YS. Antioxidative activities and contents of polyphenolic compound of Cudrania tricuspidata. Journal of the Korean Society of Food Science and Nutrition, 28: 1310-1315, 1999.

Choi H, Lee J, Shin HJ, Lee BG, Chang I, Hwang JS. Deoxypodophyllotoxin reduces skin pigmentation of brown Guinea pigs. Planta Medica, 70: 378-380, 2004.

Folin O, Denis W. A new (colorimetric) method for the determination of uric acid in blood. The Journal of Biological Chemistry, 13: 469-475, 1913.

Gray Jl, Dugan LR Jr. Inhibition of N-nitrosamine formation in model food systems. Journal of Food Science, 40: 981984, 1975.

Hagemann T, Schlütter-Böhmer B, Allam JP, Bieber T, Novak N. Positive lymphocyte transformation test in a patient with allergic contact dermatitis of the scalp after short-term use of topical minoxidil solution. Contact Dermatitis, 53: 53-55, 2005.

Han EK, Jung EJ, Lee JY, Jin YX, Chung CK. Antioxidative activity of ethanol extracts from different parts of Taraxacum officinale. Journal of the Korean Society of Food Science and Nutrition, 40: 56-62, 2011.

Han JT. Development of functional material using the root of Rosa multiflora. Food Industry and Nutrition, 11: 59-65, 2006.

Hertog MG, Hollman PC. Potential health effects of the dietary flavonol quercetin. European Journal of Clinical Nutrition, 50: 63-71, 1996.

Huang MT, Ho CT, Lee CY. Phenolic compounds in food and their effects on health $\mathbb{I}$ : antioxidants and cancer prevention. American Chemical Society, Washington DC, pp54-71, 1992.

Hwang CR, Hwang IG, Kim HY, Kang TS, Kim YB, Joo SS, Lee J,
Jeong HS. Antioxidant component and activity of dropwort (Oenanthe javanica) ethanol extracts. Journal of the Korean Society of Food Science and Nutrition, 40: 316320, 2011.

Hwang YG, Lee JJ, Kim AR, Lee MY. Chemical components and antioxidative effects of Eriobotrya japonica Lindl. leaf. Journal of Life Science, 20: 1625-1633, 2010.

Hyung SH, Gang SR, Kim YC. Effect of complex oriental medicine extract on hair growth promotion in an alopecia model of C57BL/6 mice. Journal of the Korean Society of Cosmetology, 13: 1366-1375, 2007.

Kim JH, Hong SK, Hwang SJ, Son SW, Choi YS. The preclinical and clinical effects of herbal product containing Rosa mutiflora roots extracts as a main component on the hair growth promotion. Korean Journal of Medicinal Crop Science, 20: 108-116, 2012.

Kim MK, Lee KK. Screening of physiological activities of Discurea japonica extracts. Journal of the Korean Society of Cosmetology, 19: 509-515, 2013.

Kwon MC, Han JG, Ha JH, Oh SH, Jin L, Jeong HS, Choi GP, Hwang B, Lee HY. Immuno-regulatory effect on Centella asiatica L. urban extraction solvent associated with ultrasonification process. Korean Journal of Medicinal Crop Science, 16: 294-300, 2008.

Lee JH, Park AR, Choi DW, Kim JD, Kim JC, Ahn JH, Lee HY, Choe M, Choi KP, Shin IC, et al. Analysis of chemical compositions and electron-donating ability of 4 Korean wild sannamuls. Korean Journal of Medicinal Crop Science, 19: 111-116, 2011.

Lin WH, Xiang LJ, Shi HX, Zhang J, Jiang LP, Cai PT, Lin ZL, Lin BB, Huang Y, Zhang HL, et al. Fibroblast growth factors stimulate hair growth through $\beta$-catenin and Shh expression in C57BL/6 mice. BioMed Research International, 2015: 730139, 2015.

Liu J, Kurashiki K, Shimizu K, Kondo R. 5alpha-reductase inhibitory effect of triterpenoids isolated from Ganoderma lucidum. Biological and Pharmaceutical Bulletin, 29: 392395, 2006.

Mitsui S, Ohuchi A, Hotta M, Tsuboi R, Ogawa H. Genes for a range of growth factors and cyclin-dependent kinase inhibitors are expressed by isolated human hair follicles. British Journal of Dermatology, 137: 693-698, 1997.

Mosmann T. Rapid colorimetric assay for cellular growth and survival: application to proliferation and cytotoxicity 
assays. Journal of Immunological Methods, 65: 55-63, 1983.

Oh HK. Nutritional composition and antioxidative activity of different parts of Taraxacum coreanum according to drying methods. Journal of the Korean Dietetic Association, 19: 389-399, 2013.

Park CS, Kwon CJ, Choi MA, Park GS, Choi KH. Antioxidative and nitrite scavenging activities of mugwort and pine needle extracts. Korean Journal of Food Preservation, 9: 248-252, 2002.

Park GH, Lee JY, Kim DH, Cho YJ, An BJ. Anti-oxidant and antiinflammatory effects of Rosa multiflora root. Journal of Life Science, 21: 1120-1126, 2011.

Park SJ, Choi YB, Ko JR, Kim YE, Lee HY. Enhancement of antioxidant activities of blueberry (Vaccinium ashei) by using high-pressure extraction process. Journal of the Korean Society of Food Science and Nutrition, 43: 471476, 2014.

Park SN. Effect of natural products on skin cells: action and suppression of reactive oxygen species. Journal of the Society of Cosmetic Scientists of Korea, 25: 77-127, 1999.

Peters K, Stuss D, Wadell N. Hair loss prevention through natural remedies: a prescription for healthier hair. Apple Tree Publishing, Vancouver, pp1-3, 1996.

Randall VA, Hibberts NA, Thornton MJ, Merrick AE, Hamada K, Kato S, Jenner TJ, de Oliveira I, Messenger AG. Do androgens influence hair growth by altering the paracrine factors secreted by dermal papilla cells? European Journal of Dermatology, 11: 315-320, 2001.

Ryu EM, Shin HJ. Hair growth effect of ethyl acetate and water fractions of Sparassis crispa extracts on hair-removed C57BL/6 mice. Asian Journal of Beauty and Cosmetology, 9: 295-304, 2011.
Ryu MJ, Jeong ES. A research for the development of beauty functional materials of ethanol extract of Agrimonia pilosa. Asian Journal of Beauty and Cosmetology, 10: 757-762, 2012.

Shapiro J, Price VH. Hair regrowth: therapeutic agents. Dermatologic Clinics, 16: 341-356, 1998.

Shin ES. A study on the effect of five herbal extracts on the hair growth. Journal of Investigative Cosmetology, 2: 91100, 2006.

Song MR, Mo JH. The effect of environment and genetic elements on women's alopecia. Journal of the Korean Society of Design Culture, 16: 255-261, 2010.

Stenn KS, Fernandez LA, Tirrell SJ. The angiogenic properties of the rat vibrissa hair follicle associate with the bulb. Journal of Investigative Dermatology, 90: 409-411, 1988.

Stenn KS, Messenger AG, Baden HP. The molecular and structural biology of hair. New York Academy of Sciences, New York, pp11-13, 1991.

Su HY, Hickford JG, Bickerstaffe R, Palmer BR. Insulin-like growth factor 1 and hair growth. Dermatology Online Journal, 5: 1, 1999.

Takagi S, Yamaki M, Masuda K. Lipophilic constituents of the fruits of Rosa multiflora Thunb. Yakugaku Zasshi, 100: 466-467, 1980.

Tsuboi R. Growth factors and hair growth. Korean Journal of Investigative Dermatology, 4: 103-108, 1997.

Yano K, Brown LF, Detmar M. Control of hair growth and follicle size by VEGF-mediated angiogenesis. The Journal of Clinical Investigation, 107: 409-417, 2001. 


\section{국문초록}

\section{찔레뿌리 추출물의 항산화능과 인간모유두세포의 성장인자 발현에 미치는 영향}

황현숙, 황태현, 표애자, 주은화*

조선대학교 보완대체의학과, 광주, 한국

목적: 찔레나무(Rosa multiflora) 뿌리에서 유효성분을 추출하여 항산화 활성 평가, 세포증식효과 및 성장인자 발현촉진효과를 확 인하여 천연성분을 이용한 기능성 화장품 및 육모제 소재로서의 활용 가능성을 탐색하였다. 방법: 찔레나무 뿌리에서 다양한 방 법으로 유효성분을 추출하여 총 폴리페놀 및 플라보노이드 함량을 측정하였고, DPPH 라디칼 소거능과 아질산염 소거능을 측정하 였다. MTT assay로 인간모유두세포에 대하여 세포 독성 효과를 측정하였으며, 웨스턴블롯을 통해 모발성장인자인 PDGFB, KGF, IGF1, VEGF, HGF, EGF의 발현촉진효과를 측정하였다. 결과: 찔레뿌리 추출물 6종의 총 폴리페놀 함량은 초임계 추출물(101.925 $\mathrm{mg} / \mathrm{g})$, 총 플라보노이드 함량은 초임계 추출물 $(14.365 \mathrm{mg} / \mathrm{g})$ 에서 가장 높게 나타났다. DPPH 소거능은 메탄올 초음파 추출물 (98.24\%)에서, 아질산염 소거능은 초임계 추출물(55.86\%)에서 가장 높게 나타났다. 인간모유두세포에 찔레뿌리 메탄올 초음파 추 출물을 $10,100,500 \mu \mathrm{g} / \mathrm{mL}$ 의 농도별로 처리하여 세포 독성을 확인한 결과, 처리농도 범위 내에서 세포 독성은 관찰되지 않았으며. 농도가 증가할수록 세포 생육도가 높았다. 웨스턴블롯을 통한 성장인자 단백질의 발현효과는 대조군 대비 IGF1은 $135 \%, \mathrm{PDGFB}$ 은 $126 \%$ 로 발현촉진효과가 높게 나타났다. 결론: 찔레뿌리 추출물은 독성이 없고 항산화능이 우수하였으며, IGF1과 PDGFB에 대한 발현촉진효과가 높게 나타나 항산화제, 기능성화장품, 육모제 및 발모촉진제의 천연소재로서의 활용 가능성을 확인하였다.

핵심어: 찔레나무, 인간모유두세포, 웨스턴블롯, 성장인자, MTT assay

\section{참고문헌}

권민철, 한재건, 하지혜, 오성호, 김영, 정향숙, 최근표, 황백, 이현용. 병풀의 초음파 추출 시 용매에 따른 면역활성 증진 효과.

한국약용작물학회지, 16: 294-300, 2008.

김명곤, 이근광. 참마(Discorea japonica) 추출물의 생리활성 비교. 한국미용학회지, 19: 509-515, 2013.

김중학, 홍성길, 황성주, 손상욱, 최용순. 찔레뿌리 추출물을 주성분으로 하는 천연물 조성물의 발모촉진 효과에 관한 전임상

및 임상시험 연구. 한국약용작물학회지, 20: 108-116, 2012.

류은미, 신현재. C57BL/6 마우스에서 꽃송이버섯 추출물의 에틸 아세테이트층과 물층의 분리에 따른 발모 효과. 아시안뷰티

화장품학술지, 9: 295-304, 2011.

박근혜, 이진영, 김동희, 조영제, 안봉전. 찔레나무뿌리(Rosa multiflora root)의 항산화 및 항염증효과. 생명과학회지, 21 :

1120-1126, 2011.

박성진, 최영범, 고정림, 김영언, 이현용. 초고압 처리가 블루베리의 항산화 증진에 미치는 영향. 한국식품영양과학회지, $43:$

471-476, 2014.

박수남. 천연물의 피부세포에 미치는 영향: 활성산소의 작용과 억제. 대한화장품학회지, 25: 77-127, 1999.

박찬성, 권충정, 최미애, 박금순, 최경호. 쑥과 솔잎의 항산화작용 및 아질산염 소거작용. 한국식품저장유통학회지, 9: 248-

252,2002

범희주, 김란, 김한식. 수창포의 이화학적 특성과 에탄올 추출물이 UVB로부터 피부 보호에 미치는 효과. 아시안뷰티화장품학

술지, 8: 181-194, 2010.

송미라, 모정희. 환경 및 유전적 요인이 여성의 탈모에 미치는 영향. 한국디자인문화학회지, 16: 255-261, 2010.

신은수. 5종의 한약재가 모발성장에 미치는 영향에 관한 연구. 대한미용학회지, 2: 91-100, 2006.

오희경. 흰민들레의 부위별 건조방법에 따른 영양성분 및 항산화효과 비교. 대한영양사협회 학술지, 19: 389-399, 2013. 
유민정, 정은숙. 선학초 에탄올 추출물의 미용기능성소재 개발을 위한 연구. 아시안뷰티화장품학술지, 10: 757-762, 2012. 이진하, 박애리, 최대운, 김종대, 김진철, 안주희, 이현용, 최면, 최근표, 신인철, 등. 산나물류의 식품 화학적 성분과 전자 공 여능. 한국약용작물학회지, 19: 111-116, 2011.

차재영, 김현정, 정정한, 조영수. 꾸지뽕나무(Cudrania tricuspidata)의 폴리페놀 화합물 함량과 항산화 활성. 한국식품영양과 학회지, 28: 1310-1315, 1999.

한은경, 정의진, 이지영, 김영섭, 정차권. 민들레의 부위별 에탄올 추출물의 항산화 활성. 한국식품영양과학회지, 40: $56-62$, 2011.

한재택. 찔레뿌리를 활용한 기능성 소재의 개발. 식품산업과 영양, 11: 59-65, 2006.

형순희, 강성례, 김영철. $\mathrm{C} 57 \mathrm{BL} / 6$ 마우스 모델에서 복합 한약추출물의 모발성장 촉진효과. 한국미용학회지, $13: 1366-$ 1375, 2007.

황윤경, 이재준, 김아라, 이명렬. 비파잎의 이화학적 성분과 항산화효과. 생명과학회지, 20: 1625-1633, 2010.

황초롱, 황인국, 김현영, 강태수, 김윤배, 주성수, 이준수, 정헌상. 미나리 에탄올 추출물의 항산화성분과 항산화활성. 한국식 품영양과학회지, 40: 316-320, 2011. 


\section{中文摘要}

\section{菩薇树根提取物的抗氧化效能和人毛囊真皮乳头细胞成长因子表达的影响}

黃賢淑，黃太鉉，表愛子，朱銀花*

朝鲜大学补完代替医学科, 光州, 韩国

目的：在蓄薇树根中提取有效成分，评价其提取物的抗氧化活性、细胞增殖效果及成长因子表达促进效果，探讨作为功 能性天然化妆品及育发剂原料的应用可行性。方法: 在菩薇树根中利用多种方法提取有效成分, 分别测定总多酚含量和 类黄酮含量, 并测定DPPH自由基消除能力和亚硝酸盐的消除能力。对人毛囊真皮乳头细胞利用MTT assay法来测定细胞 毒性，应用Western blot测定PDGFB、KGF、IGF1、VEGF、HGF、EGF等生长因子的表达促进效果。结果：在6种萻薇树 根提取物的总多酚含量和类黄酮含量中, 其中超临界萃取物以总多酚为 $101.925 \mathrm{mg} / \mathrm{g}$, 类黄酮含量以 $14.365 \mathrm{mg} / \mathrm{g}$ 显示最 高。DPPH消除能力在甲醇超音波提取物中以 $98.24 \%$ ，亚硝酸盐消除能力在超临界萃取物中以 $55.86 \%$ 显示最高。对人毛 囊真皮乳头细胞, 利用蓄薇树根甲醇-超音波提取物分别以不同浓度 $10,100,500 \mu \mathrm{g} / \mathrm{mL}$ 进行处理, 测定细胞毒性结果显 示: 在处理浓度范围内没有观察到细胞毒性, 浓度越高, 细胞生长速率越高。利用Western blot检测细胞成长因子的蛋白 质表达结果显示: 与对照群相比IGF1以135\%, PDGFB以126\%显现高效果。结论: 蔷薇树根提取物没有毒性，具有优秀的 抗氧化能力, 对IGF1和PDGFB的表达具有高促进效果。因此作为抗氧化剂、功能性化妆品, 育发剂以及发毛促进剂的天 然原料充分具有可行性。

关键词：蔷薇树，人毛囊真皮乳头细胞，Western blot，成长因子，MTT assay 